\title{
OUtRo DESTINO
}

\section{Entrevista concedida por Eduardo Viveiros de Castro a Maria Inês de Almeida}

Ontropólogo Eduardo Viveiros de Castro desenvolve um pensamento, em diálogo com a Filosofia, que tem se tornado referência para algumas experiências literárias e de ensino. Ao lado da escritora portuguesa Maria Gabriela Llansol, produz um efeito sobre o Núcleo de Pesquisas Literaterras, que, de alguma maneira, influencia as práticas desse grupo, levando-o a formulações que orientam certa posição nos projetos literários e escolares com os índios. Nesta conversa, que aconteceu no Rio de Janeiro, em 20 de setembro de 2007, o pesquisador do Programa de Pós-Graduação em Antropologia Social, do Museu Nacional da UFRJ, expõe algumas idéias sobre o tema proposto pela Aletria: Alteridades hoje.
Aletria - "_-___ talvez o meu texto venha um dia a desaparecer. Não deixará de ser verdade que nasceu aqui.
Entre vós, na minha língua confrontada às vossas paisagens. Que podeis compreender e identificar sem, no entanto, desvendar a língua que foi a sua raiz. Por outro lado, os portugueses, que nem as vêem, nem as identificam, nem são embebidos por elas, podem ouvir a língua que as fala.
Esta sobreimpressão, à primeira vista discordante e contraditória, não surgiu por minha livre vontade. Impôs-se-me, embaraçante e complexa, e exigiu de mim mesma uma mutação para a qual nada, nem ninguém, me tinha preparado.
Eis o que aconteceu realmente: Sei hoje que é nessa sobreimpressão que eu habito o mundo, e vejo, com nitidez, que outros vieram a ter comigo:
'concebe um mundo humano que aqui viva, nestas paragens onde não há raízes'."

Lisboaleipzig I. O encontro inesperado do diverso.

Quando Maria Gabriela Llansol escreveu isso, ela se referia a sua própria vidal escritura na Bélgica, sendo ela portuguesa. Mas eu me aproprio do seu texto e o transfiro para os indios, dizendo que os textos que eles estão produzindo são sobreimpressos à paisagem brasileira. Você acha possível relacionar esse conceito de sobreimpressão à literatura ameríndia?

Viveiros de Castro - Umas coisas que o Deleuze escreve sobre um poeta romenofrancês, o Gherasim Luca, e que é o que ele chama de gaguejar na própria língua. Não gaguejar na própria língua, mas fazer a própria língua gaguejar. O Gherasim Luca é um autor interessantíssimo, que escrevia em francês, e que tem poemas maravilhosos que são exatamente isso: ele faz o francês funcionar como uma gagueira, porque ele percebe o fato. Isto não é o Deleuze que fala, mas eu que, como lusoparlante, vejo: ele percebe que o francês é uma língua completamente homofônica, cheia de sílabas que são idênticas escritas de maneira diferente, mas idênticas quanto ao som. Palavras e 
monossílabos que têm sentidos diferentes, mas que se escreve igual: osso, água, vinho, vento, uma série de coisas que soam parecido, e o Gherasim Luca decompõe as palavras do francês e produz uma língua gaguejante baseada nessa propriedade que o francês tem de ser uma língua cheia de homófonos. E produz uma fala completamente alucinatória. Eu fico imaginando se os índios, também, não terminarão por fazer isso: fazer o português gaguejar, digamos assim. A palavra não é esta, mas é este o efeito, o equivalente em português eu não sei como chamar. $\mathrm{O}$ que o Oswald chamou, ainda numa linguagem valorativa que não seria mais a que se usa hoje, e que ele chamava de "contribuição milionária de todos os erros". A palavra "erros" teria que ser tomada com aspas agora. Ele não precisava botar aspas, porque já estava dizendo que as contribuições são milionárias.

O português brasileiro: a contribuição milionária é o falado errado, o falado no Brasil. Essa idéia de contribuição milionária de todos os erros é uma idéia interessante. Só os erros são milionários, só eles permitem intuir o que é ser alguma coisa. Eu vejo a idéia de sobreimpressão, que é uma idéia de sobreposição sem superposição, no sentido de coincidências entre as duas línguas, os dois códigos, as duas formas de impressão, que produz um efeito de refração, de gaguejo, de repetição diferenciada, de erro, de imprecisão. A necessidade da imprecisão, chamemos assim: a imprecisão nítida, que é uma virtualidade muito rica a ser explorada, e que de repente as expressões indígenas podem suscitar.

Aletria - "Para o tupi, o outro não é um espelho, é um destino" (Eduardo Viveiros) e "O brasileiro vive a triste contradição entre ser o outro e não ser nada” (Paulo Emílio Sales Gomes). Estas duas frases ecoam na minha cabeça, intrigantes, uma porque representa uma vertente da relação com o outro, a que nos libera do modelo. Outra, porque representa a vertente da dependência. Como você, hoje, colocaria essa questão da alteridade, tendo em vista a relação da inteligência brasileira com o "indio" e o "branco"? Quem, ou o que, é o outro, para você?

Viveiros de Castro - Tem essas duas frases que você joga uma contra a outra, e muito a propósito, então eu digo que "para os tupi, o outro não é um espelho, mas um destino", e a frase do Paulo Emílio que diz que o "brasileiro vive a triste condição de ser o outro ou não ser nada”, essa frase é muito triste. É uma contradição, uma certa imagem do brasileiro. É uma imagem muito ruim do brasileiro que, ao mesmo tempo, é narcísica, um narcisismo sofredor, masoquista. A contradição entre ser o outro e não ser nada, na verdade - é como se ele estivesse dizendo - é uma contradição, porque é entre ser dois nadas, porque se é o outro não é nada também, visto que só o eu é. É como se, no fundo, só o eu fosse, então é uma frase entre ser o outro e não ser nada, porque não tem identidade. Esse é o ponto. 
Aletria - Estamos trabalhando com a hipótese de que é neste ponto zero que se escreve. A literatura (e aí a gente pode abandonar o "brasileira", porque eu não sei se tem muito cabimento "literatura brasileira") escreve neste ponto, quando o sujeito zera.

Viveiros de Castro - Sim, claro. Ele está justamente naquele momento de hesitação entre ser o outro e não ser nada. É só ali que surge alguma coisa. E é interessante que o Paulo Emílio tenha chegado nessa frase, mas é espantoso que ele tenha chegado a essa conclusão escrevendo muito depois, eu suponho, num mesmo lugar físico e num tempo cronológico muito posterior, ao que o Oswald já tinha mostrado, que justamente essa não é uma escolha que nos concerna. Ao contrário: o Manifesto Antropófago é justamente o contrário dessa frase, de que nós vivemos prisioneiros da triste contradição entre ser o outro e não ser nada. Esse ser ou não ser o outro do Oswald diz: não tem contradição, a questão é tupi or not tupi. Ele já tinha resolvido o problema muito antes do Paulo Emílio vir. O interessante é que parece que este é um problema paulistano, não é um problema brasileiro. É um problema da elite da burguesia intelectual paulista.

Aletria - Por isso que o Oswald não conseguiu entrar para a USP...

Viveiros de Castro - Por isso que o Oswald era aquela figura paradoxal, meio monstruosa em todos os sentidos, um dândi afrancesado, que foi, entretanto, um dândi semi-intelectualizado capaz de articular o discurso mais radical sobre as condições de possibilidade de uma brasilidade não alienada, digamos assim, que não ficasse precisamente presa nessa alternativa, apresentada pelo Paulo Emílio, entre ser o outro e não ser nada, como se tivesse uma terceira, como se fosse possível uma outra coisa, como se esse fosse o único jogo possível. E esse outro que o brasileiro contradiz, se o for, é um outro que é alguma coisa, e este, sim, é um eu.

O Paulo Emílio disse que o brasileiro não tem condição de ser europeu ou não ser coisa nenhuma. Esse outro aqui é o europeu, evidentemente. E aí é como vai dizer o outro lá (citando Duchamp, numa frase que eu adoro): "Não há solução porque não há problema". E isso que ele está fazendo é justamente criando um problema para o qual não há solução. Mas não há solução porque não há problema. A solução já foi dada por Oswald: "Só me interessa o que não é meu". É uma grande frase, que eu acho que se junta a "não é um espelho mas é um destino".

Aletria - Esta frase, que acho muito responsável por sua presença na Faculdade de Letras, é interessante porque ficou como uma máxima, um dístico, latejando em nosso grupo, ainda antes da presença dos índios; e ela funcionou como uma espécie de guia. E quando eu li A inconstância da alma selvagem, fiquei pensando: será que o Eduardo Viveiros de Castro se sentia inspirado pelo Manifesto Antropófago? Até que ponto Oswald de Andrade o teria influenciado? 
Viveiros de Castro - Essa é uma questão que já me foi colocada, que eu já me coloquei, e que só fui pensar nela bem depois, porque, de fato, quando eu era estudante secundarista, estava no colegial, em 67/68, estava no auge de um grande debate intelectual dentro da cultura brasileira, sobre quais eram as alternativas disponíveis para a constituição de um discurso desalienado, desalienante, do ponto de vista do que seria uma cultura brasileira. E a discussão, na época, era justamente o que era cultura e o que era brasileiro. Havia aqueles que achavam que cultura era só alta cultura ou só cultura popular. E aqueles que achavam que brasileiro era só o que era folclórico, ou historicamente autóctone, ou coisa parecida. E havia aqueles que achavam o contrário, que a cultura moderna não era popular, era pop, digamos assim, uma cultura de massa, e que faziam um uso crítico da cultura de massa, e achavam que a cultura era transnacional, translocal. Era, na verdade, o debate envolvendo o Tropicalismo, envolvendo o CPC (Centro Popular de Cultura). Havia a teoria do nacional-popular, assim chamada, que era a doutrina do Partidão, do Partido Comunista, em suma, da esquerda clássica, conservadora e paternalista, que derramava lágrimas de crocodilo quando via um samba de raiz, e que era ao mesmo tempo paternalista em relação às suas expressões populares. Ser chamado popular já tinha toda uma ambigüidade.

De outro lado, havia aquele pessoal definido como alienado, americanizado, porque gostava de guitarra elétrica, de tecnologia, de Beatles, de rock, de drogas, ao invés de revolução, e que tinha por trás Caetano, Gil, o Tropicalismo. Tudo estava acontecendo justamente naquele momento em que havia uma espécie de escolha existencial meio... O Gabeira foi uma espécie de símbolo dessa bifurcação existencial. Era, "afinal de contas, preciso fazer uma revolução social sem fazer uma revolução conceitual, mental”. Se fosse possível mudar as formas do Estado sem mudar as formas de vida...

E foi neste contexto que eu saí do Científico para o Clássico, ou seja, eu troquei de formação no meio do meu Colegial. Quando eu passei para o Clássico, eu comecei a ler literatura, comecei a ler mais essas discussões de suplementos dominicais, que, na época, valiam alguma coisa. E foi aí que eu topei com os irmãos Campos, com a Poesia Concreta, com esses debates, com O balanço da bossa, do Augusto de Campos, que foi um livro fundamental pra mim, justamente porque figurava toda essa discussão, que mostrava o que havia de sofisticado e revolucionário, do ponto de vista filosófico, nessas manifestações supostamente pop, populares, de "baixa cultura", tipo música popular, rock, etc.

O livro chamava a atenção para o que ele tratava como linha evolutiva da música popular brasileira, para o paideuma, onde estava a ponta de vanguarda perene que atravessava vários estratos da literatura brasileira, mas de uma maneira transversal, que pegava, sei lá, o Gregório de Mattos, o Caetano Veloso, passando por uma série de autores, toda aquela recuperação da literatura e da poesia barroca. Por exemplo, o Haroldo, com outro livro fundamental que é $O$ seqüestro do barroco e a formação da literatura brasileira 
que eu acho que é um livro que provocou um enorme escândalo na academia paulistana, mas que é um livro fundamental.

Todo esse componente precisamente barroco, conceptualista, se conectava com o mais extremo oposto, que é o pessoal da guitarra elétrica, digamos assim. Nisso tudo é que eu fui tomar contato com o Oswald, através dos irmãos Campos, da leitura que o Haroldo e o Augusto faziam da poesia do Oswald e da teoria antropológica do Oswald. O Manifesto Antropófago, desde então, sempre me pareceu como a única forma possível de um brasileiro escapar da chamada triste contradição do outro.

Como diria Deleuze, fazer passar uma linha de fuga entre os dois pólos de uma contradição, cortá-la no meio e sair do outro lado. É como dar o pulo do gato, em outras palavras, dar o pulo da onça. Seria como sair dessa, ao invés de ficar eternamente preso entre o espelho e o nada. A teoria do medalhão do Machado: eu vou olhar e não tem mais nada, então eu sou o outro ou não sou o nada. Não tem terceira posição? Bom, diria o Oswald, só me interessa o que não é meu. Talvez o único modo de escapar dessa contradição é quebrando o espelho, passando por dentro dele.

Eu fiquei fascinado com o que me parecia a simplicidade genial, e, ao mesmo tempo, com a cara meio provocadora, meio brutal, das formulações do Oswald. Mas isso não teve nenhuma relação com a minha escolha pela Antropologia, que não passou por aí, não teve uma relação com isso. Eu fui parar na Antropologia porque fui aluno do Luís Costa Lima, na Sociologia da PUC, e não agüentava aquela sociologia que se ensinava na época, da teoria da dependência, e redenção, e terceiro mundo e não sei o quê. E o Luís, na época, estava lendo Lévi-Strauss para a tese de Doutorado que ele estava escrevendo. E foi lendo as Mitológicas, do Lévi-Strauss - o Luís tinha interesse nestes movimentos de análise textual, o estruturalismo enquanto análise textual - que eu fui descobrir os índios. E, de imediato, eu não conectei esse índios que eu descobria nas Mitológicas, que eram reais, de carne e osso, com os índios bandeira-política e exemplo metafísico que o Oswald tinha usado no Manifesto.

Aletria - E o indio foi desde sempre o grande mito da literatura brasileira, desde a Colônia...

Viveiros de Castro - E eu não conectei os dois, em parte talvez porque, de fato, a conexão não fosse tão fácil. Ainda que a conexão tivesse sido feita, por exemplo, pelo Mário de Andrade. Isso é interessante, porque o Mário vai tematizar, no Macunaíma, o canibalismo, a antropofagia. De alguma maneira, eu acho que não foi ele que tirou da literatura indígena o que havia de mais radical. Foi o Oswald, que na verdade não tinha nenhuma relação com a literatura indígena propriamente dita. A conexão dele é com os cronistas, cientistas, com a Brasiliana arcaica, Gabriel Soares de Souza, essas coisas todas, é por aí que ele vai pegar os índios. Enquanto que o Mário, como bom pesquisador, bem acadêmico e bem comportado, vai lá buscar um texto genial, que é este texto, este mito wapixana, que é o mito do Macunaíma. Mas, por 
alguma razão, eu sempre achei que o Manifesto Antropófago falasse muito mais que o Macunaíma. E quando eu fui ler o Lévi-Strauss, fui ler os mitos, foi por aí que eu fui parar na Antropologia. Foi pelo texto, foi pela literatura, num certo sentido, porque foi pelos mitos, não foi pela Sociologia. Foi para fugir da Sociologia que eu fui parar na Antropologia, e foi até certo ponto pela Literatura que eu cheguei lá. E então fui trabalhar com os índios.

E quando comecei, fui parar nos Tupi também por acaso, porque tinha trabalhado antes no Xingu, tinha feito trabalho nos Yanomami... É claro que todos os índios são Tupi num certo sentido. Mas foi quando eu fui trabalhar com um grupo que falava uma língua Tupi, que comecei a estudar o material do Tupi clássico, esse material que tinha inspirado o Oswald. As fontes quinhentistas, os jesuítas, os cronistas franceses. Foi ao estudar o material Tupi que eu comecei a tratar o canibalismo como um objeto, a antropofagia como uma questão antropológica enquanto tal, o que me levou a uma série de desenvolvimentos teóricos.

Essa idéia de o outro não é um espelho, mas é um destino é uma interpretação, um resumo poetizado, a bem dizer, uma fórmula poética que resume uma determinada interpretação da antropofagia que eu faço. É uma interpretação, embora não derive, conscientemente, nem sequer organicamente, da leitura que faz o Oswald da antropofagia. A posteriori, eu vejo que, na verdade, é uma coisa que ele já dizia. E é o que eu já tinha lido. Só que, de alguma maneira, isso tinha ficado submerso no meu inconsciente, porque estava em outro departamento da minha memória, digamos assim.

Aletria - Essas coisas se juntam em momentos diferentes e, às vezes, cada autor cria seus precursores, a gente cria na leitura os precursores de cada autor, e é muito incrível hoje a gente ver os indios na universidade. Eles estão na UFMG todo mês de maio e setembro. A gente lá mergulhada, 142 indios e tal. E o tempo todo essas questões filosóficas e poéticas, que o seu texto traz, e o do Oswald também, são muito fundamentais pra gente. E fica ecoando, com os indios lá, trabalhando: a poesia existe nos fatos. É como se a gente pudesse - e eu queria que você falasse disto finalmente, minimamente, comer o biscoito fino que o Oswald preparou.

Viveiros de Castro - Eu espero que os índios modifiquem a universidade antes que a universidade modifique os índios, ou melhor dizendo, eu espero que uma coisa não se faça sem a outra, porque modificar é bom, em geral. Se as coisas se passarem como deveriam, do ponto de vista de um deus indígena, eu diria que o bom mesmo seria se, desse encontro, a universidade não saísse ilesa. E, sem dúvida, não vai sair. Por várias razões. Primeiro porque a universidade brasileira é fraca, graças a Deus. No sentido de que ela não tem ainda uma máquina de moer carne tão bem azeitada como a universidade francesa tinha (pois já não tem), ou uma grande universidade da Alemanha. Então, isso, de repente, essas impurezas colocadas no interior da máquina universitária que, pensando bem, não são mais impuras que tudo aquilo que cai dentro da máquina universitária - permitem, de alguma maneira, fazer derrapar num 
poço esse caminhão, esse carro. Supostamente, é a universidade que transportaria tudo para o paraíso da cultura, o paraíso da cidadania. Eu ponho fé.

Por outro lado, a gente não pode ficar prevendo o futuro dos outros. $\mathrm{O}$ nosso já é quase impossível, o dos outros é uma coisa tão absurda, não sei se é arrogante, de tão absurdo que é. Mas você fica imaginando. Minha impressão é que boa parte do que está acontecendo no mundo, na área da Antropologia, com certeza, de revisão radical, de repensar a tradição cultural ocidental, é devido ao fato de que a plebe do terceiro mundo foi parcialmente admitida no sistema universitário, e foi a ela dado um certo acesso aos fóruns culturais dominantes: os intelectuais indianos, os intelectuais africanos, os intelectuais que começam a penetrar na universidade do primeiro mundo. São as mulheres, que não entravam na universidade do primeiro mundo até não muito tempo atrás, na Inglaterra, nos Estados Unidos. E desses lugares saiu um discurso contestador poderoso. Então, a capacidade que têm esses aparelhos de Estado, como a Universidade, de realmente formalizar o elemento perturbador, não é tão grande, nem é tão impotente, pelo contrário: a máquina começa a ranger, pois dentro dela há gente que gagueja a língua, faz sobreimpressão, que põe as coisas fora do lugar.

Há uma famosa análise do Roberto Schwartz, autor que eu respeito e admiro: as idéias fora do lugar. Mas eu sempre tive implicância com essa frase. Eu sempre achei que as idéias sempre tinham que estar fora do lugar mesmo, e que não há idéia no lugar; que, quando as idéias estão no lugar, dá no que dá, deu no que deu. Então a frase das idéias que estão fora do lugar lembra um pouco a triste contradição, vem da mesma episteme: essa idéia da contradição entre ser o outro ou não ser nada. Fica essa sensação e você fica se perguntando: mas quem são vocês para dizer qual é a minha triste contradição? Minha quem, cara-pálida? Triste? Contradição? Brasileiro? Tudo aqui é colocado em dúvida. O que significa ser o outro? É imitar? É ser um espelho? Ou é ser um destino? Qual a diferença entre tomar o outro como espelho ou como destino? E o que significa ser nada? É algo tão ruim assim? Se ser nada significa recusar a identidade como um objetivo na vida, "Será que eu vou ter uma identidade quando crescer?". Parece que é isso que ele está dizendo ao brasileiro, que ele não tem uma identidade, que ele está preso entre ter uma identidade alheia, ou não ter nenhuma. A pergunta é: isso é um defeito ou é uma qualidade, uma vantagem? Isso é um defeito de saída? É um handcap positivo ou negativo? O Oswald diria: é positivo, é justamente por aí que temos que ir.

Aletria - Porque o "Matriarcado de Pindorama" é radicalmente contra a identidade.

Viveiros de Castro - Só me interessa o que não é meu é uma frase genial, se lida em um sentido anti-capitalista. "Se só me interessa o que não é meu, então eu quero para mim, e é aí que vai ficar bom.” Não é assim. Só me interessa o que é meu enquanto não é meu. O movimento é um movimento pra fora, um movimento 
anti-narcísico. Só me interessa o que não é meu é o contrário do narcisismo, do narcisismo "só me interessa o que é meu", que é o nacional, as raízes nacionais, a volta pra o cinismo e tal. E o outro reclama que não temos esse cinismo para o qual voltarmos, como se isso fosse uma triste condição. O Oswald dizia, contra isso, que é uma alegre contradição, a palavra é alegre, "a alegria é a prova dos nove”. Então o outro fala em triste contradição. Se a alegria é a prova dos nove, esse aqui não passou na prova. Pois, como vai dizer a Maria Gabriela Llansol, onde existe o prazer, o conhecimento está próximo. Tem gente que acha que é preciso muita tristeza, muita dor - é o dolorismo - pra chegar ao conhecimento, a identidade e tal.

Aletria - Aí a gente chega numa outra questão importante para essa entrevista, que é a questão da literatura e dos livros dos índios. Porque, hoje, a Faculdade de Letras está produzindo e editando, em convênio com o MEC, desde 2004, livros produzidos no Brasil inteiro, em programas de educação. É um material escolar. O nosso grupo de pesquisa fez um convênio com o MEC, porque a gente já estava fazendo esse trabalho dentro da universidade. E estamos fazendo muito livro. Nos últimos dois anos saíram uns trinta títulos.

Viveiros de Castro - E como você avalia a variação interna dessa literatura?

Aletria - Este é o ponto em que eu queria chegar. Porque, juntando as duas coisas, o índiogrande outro da universidade - mais esse devir indígena da universidade, a gente acaba forjando algo, que é no sentido de abandonar um critério idealista, essencialista, de qualidade literária. Porque muitos livros nunca tiveram a menor pretensão de constituir literatura. São textos que, se você pensar nas disciplinas tradicionais, seriam muito mais de Geografia, Historiografia, Agronomia, ficção mesmo até agora não vi nada. Há o que a gente chama, com a Antropologia, de mitologia, narrativas que os índios chamam "nossas histórias verdadeiras", e há também histórias e textos construídos a partir da relação deles com os brancos, com os não índios. Tudo em função da escola que pretendem criar, sendo feito, na maioria das vezes, nas línguas, ou bilíngües.

Viveiros de Castro - Pedras de rosetas, não é? Chaves de decifração da cultura ocidental por eles, e vice-versa. Textos técnicos, manuais.

Aletria - Como se fosse isso, como se estivéssemos na pré-história...

Viveiros de Castro - Como aqueles escritos cuneiformes, listas de boi, listas de bens do palácio, instruções de como utilizar a ortografia, como utilizar o saber dos brancos, gramática, o vocabulário, etc. E as mitologias, fortemente formalizadas e já objetivadas como aquilo que deve ser escrito...

Aletria - Que já está dentro daquilo que poderíamos chamar de literatura oral. Já são escritas na oralidade.

Viveiros de Castro - É, eles são na verdade objetificados com ganhos e perdas, ambos consideráveis, no sentido que não vai mudar... 
Aletria - Aquilo que tenho relatado em meus textos como um processo tradutório, uma coisa incessante. E que não tem encontrado barreira institucional, porque o $\mathrm{CNPq}$ tem sistematicamente financiado nossas pesquisas, quer dizer, pelo menos as pessoas que estão em algum lugar, julgando esse trabalho, estão investindo, os órgãos oficiais estão deixando a gente fazer e até subsidiando, porque gasta-se muito dinheiro nisso, fica caro esse processo tradutório. Trazer um índio para uma oficina na UFMG e mantê-lo ali quinze dias é um negócio caro demais.

Viveiros de Castro - Eu não sei, acho que vai acontecer, não sei se é como está acontecendo, mas seria interessante comparar, e eu fiquei especulando ociosamente, com isso que os índios fizeram com o vídeo. Toda a apropriação do vídeo pelos índios, variada, uma série como o "Vídeo nas aldeias", onde você tem as coisas mais variadas possíveis, e tudo o que veio antes, com os primeiros vídeos produzidos pelos índios, o pessoal filmando os rituais, e aprendendo a filmar, ou aprendendo a desaprender a filmar, ou desaprendendo a aprender a filmar, ou aprendendo a filmar do jeito indígena. E se não é uma coisa que vai acontecer com a palavra impressa, quer dizer, é um determinado uso que a gente não sabe no que vai dar...

A gente só sabe que o que está acontecendo é necessário para que o que venha a acontecer. A possibilidade dessa intervenção indígena na literatura, ou na letra, na impressão, na palavra impressa, vai depender muito do tamanho, do volume que isso atinja... Porque, veja só o que acontece: a população branca, pobre e não indígena no Brasil tem uma relação muito diferente com isso. Não existe uma entrada de um camponês da Amazônia na universidade, você não vê esse fenômeno. Agora você vê com os indígenas, porque os indígenas possuem e existe uma outra linguagem rolando, uma sobreimpressão. A impressão é que no outro caso você não tem uma sobreimpressão. Você tem o analfabeto, o analfabetismo, como uma história de privação do alfabeto, do alfabetismo, do letramento.

No caso dos indígenas é interessante porque não é isso que se passa. Não é um problema de analfabetismo, ou de alfabetização. Ainda que o seja do ponto de vista descritivo, técnico, não é isso que está se passando do ponto de vista da teoria antropológica. O que está se passando é uma transversalização de duas culturas, ou várias culturas, e ao mesmo tempo a exposição da literatura a um regime do ser radicalmente diferente daquele ao qual ela está associada, àquilo que você falou, que a poesia se encontra nas coisas, como nesses manuais de geografia...

Aletria - Eu chamo isso de poesia, de literatura, mas numa esfera que é a do "pulo da onça", que pega outra linhagem. Mallarmé, por exemplo, a proposta do Mallarmé, o lance de dados do Mallarmé, tudo o que ele fez com a poesia, como a poesia dele se realiza na dança. Quando você vê a literatura sair da letra e virar ato, e virar página branca, e virar um movimento, fica pensando: mas então isso que os Maxakali estão fazendo aqui no papel é literatura de vanguarda. 
Viveiros de Castro - Mas a civilização ocidental é aquela coisa, é um nome impróprio, como se fosse uma coisa só, como se fosse uma mega-pessoa, uma megaentidade, quando na verdade é uma multiplicidade contraditória, cheia de virtualidades. A civilização ocidental é uma monstruosidade de um milhão de culturas diferentes que se fundiram e se contradisseram e se juntaram, e tem de tudo dentro. É por isso que ela é uma civilização, não é uma cultura, no sentido de uma cultura isolada.

Por que chamá-la ocidental ou européia? Porque aquele lugar é, do ponto de vista geográfico, um lugar bem situado, digamos assim, aquele cara que bota suas coisas pra vender na beira da estrada vende mais do que o outro cara que coloca pra vender no meio do nada. A Europa está naquele ponto no fim da Eurásia, que é um lugar continental privilegiado, que está entre a África, a Ásia e o Oriente Médio. Ali bate a onda que vem da Ásia e da África e pára, e reflui, e fica fermentando. Agora, naturalmente que junto a tudo isso, tudo o que é europeu não é europeu, a religião é semita, a escrita é fenícia, a filosofia é meio grega, meio hindu, meio não sei o quê, a egípcia... Ou seja, a Europa é só o nome de um gigantesco processo de digestão canibal de milênios. Acho que é o Heródoto que cita os egípcios, que já tinham três, quatro mil anos de civilização, que diziam, quando olhavam os gregos: "Vocês são crianças, vocês não sabem de nada."

Os gregos, que inventaram a civilização ocidental, não sabiam de nada, porque eram crianças. De certo modo, você pode imaginar os europeus dizendo aos brasileiros: vocês são crianças, vocês não sabem de nada. E eles, lá dos seus quatro mil anos de cultura, como os egípcios, pode ser que não durem mais, que não durem muito, que quem vai pegar a herança deles sejam outros.

Por outro lado, você tem civilizações mais antigas que os egípcios que continuam aí, como os chineses, por exemplo, e que são formidáveis, em todos os sentidos da palavra. E tem esse pessoal aí perdido, esses pequenos planetas, meteoros ou cometas que passam antes ou rente dele, e que atravessam e cruzam o firmamento, e que podem, se passarem muito perto da terra, tirar a terra dos eixos, depende de uma série de contingências.

A impressão que eu tenho é que no Brasil está se acumulando uma série de eventualidades, de contingências, que fazem com que a universidade se abra, porque há um governo que, com todos ou seus defeitos e problemas, é um governo de esquerda, que produziu conquistas que são inegáveis em várias áreas, avançou enormemente. Outros governos anteriores também avançaram em certa direção, nem sempre porque queriam, ou sabendo o que estavam fazendo. O fato é que houve um avanço enorme. A universidade se abriu, também porque não podia mais se fechar, porque está meio em crise. Mas essas feridas, como as cotas, como a universidade indígena, vão modificar a universidade radicalmente, e a elite morre de medo disso. Não só porque vai tirar dela seus privilégios, sua prisão especial; porque agora tem muita gente que vai querer prisão especial... 
Aletria - Você acha que os índios, escrevendo em suas línguas, traduzindo, vão tirar a força da etnografia? A Etnologia pode ser auxiliada pela escrita dos próprios índios? Um povo que pega a escrever mesmo substitui o etnógrafo?

Viveiros de Castro - Eu acho que não tem nada uma coisa com a outra. Esta é uma concepção errônea muito comum, que o etnógrafo é o índio de plantão, que está lá enquanto o índio não puder escrever sua própria cultura. Agora eu vou parodiar de maneira humorística a frase do Paulo Emílio: o etnógrafo, é o seguinte, ou ele é o outro ou não é nada. Não tem etnógrafo de si mesmo. O etnógrafo tem que ser estrangeiro.

Os índios já estão fazendo etnografia. Essa literatura deles já é etnográfica, na medida em que envolve uma conexão complexa com os termos, as relações e as categorias de uma cultura alheia à deles. Estão fazendo, na verdade, uma "auto-etnografia", porque é uma etnografia que passa pela linguagem do outro. Isso vai ser sempre assim. Essa idéia de que quando os índios começarem a escrever não vai mais precisar haver antropólogo é bobagem. Os antropólogos não vão precisar fazer uma série de coisas que fazem hoje. Eles fazem, mas que não são o essencial da Etnologia, da etnografia, como se imagina. Você faz porque não existe, porque não tem índio que tenha feito antes. Quando o etnógrafo faz uma etnografia do Ocidente... Porque você pode fazer uma etnografia da universidade, da ciência...

A Antropologia da Ciência é uma disciplina muito importante, que está se desenvolvendo muito agora, e que eu acho muito estratégica desse ponto de vista, mostrando como não se faz só etnografia do analfabeto. Etnografia não é um privilégio do letrado sobre o analfabeto. Etnografia é o privilégio do outro, sem dúvida. Como é que esse privilégio pode ser usado de maneira não ofensiva, não explorativa, não colonial? Aí, quando os índios começarem a escrever, poderão mudar as regras do jogo nesse sentido. Mas vai mudar menos porque eles vão poder fazer etnografia de si mesmos, e mais porque vão começar a fazer etnografia de nós. É isso que vai mudar mais, porque etnografia de si mesmo, a rigor, não tem muita graça.

Aletria - E sobre a definição do outro? O outro é um conceito complicado, eu não gosto muito do termo. E é o tema desta revista: alteridades hoje em dia.

Viveiros de Castro - Outro é um tema que entrou em voga, de certa maneira, em certas conjunções pós-estruturalistas, e com as mais diferentes definições possíveis: Derrida, Lévinas, Deleuze, Lacan, Lévi-Strauss, e cada um usando de uma maneira bastante diferente dos outros. Eu não sei, mas isso tem a ver com Hegel; remete a Platão. É um tema clássico da metafísica ocidental: o problema do mesmo e do outro. O que a gente pode dizer, fazendo uma generalização praticamente caricatural, é que, de alguma forma, a metafísica ocidental sempre se caracterizou por demonizar o outro. O outro é uma espécie de demônio. O princípio da variação, da diferença, da alteridade, justamente em oposição a um princípio teológico, metafísico do mesmo, da semelhança, da identidade, da coincidência, da verdade. 
A verdade é uma, o erro é múltiplo. A verdade é o eu, o erro é o outro. Uma coisa que caracterizaria uma oposição assimétrica forte entre o eu e o outro ou o mesmo e o outro é a associação do eu com o mesmo e do outro com o outro. O que você vai encontrar nos anos sessenta, como talvez um pano de fundo comum a todas essas utilizações da noção de alteridade, do Lévinas ao Deleuze, e os dois são completamente diferentes, passando pelo Estruturalismo, pelo Lévi-Strauss, pelo Saussure, pela idéia da diferença, é um novo regime em que há uma súbita inversão do tabuleiro, e o mesmo aparece como a raiz de todos os pecados ocidentais, um pouco como uma hybris.

Há uma frase do Sartre, "o inferno são os outros”, e o Lévi-Strauss vai pegar o Sartre no pé com essa frase, porque ela resume a atitude ocidental em relação à alteridade, em que o demônio é o outro, portanto, o mundo bom é o mundo sem outro, em que estou sozinho. E o Lévi-Strauss vai dizer: não, a Antropologia mostra, os índios já dizem que, na verdade, o inferno somos nós, o inferno é o eu sozinho. Fora do outro não há salvação. É como se, de repente, nós nos déssemos conta de que, enquanto fixarmos o eu com a ponta do compasso e fizermos o outro rodar à nossa volta, nessa revolução copernicana, produziremos uma quantidade de conseqüências, efeitos colaterais muito deletérios. Isto está na raiz da arrogância ocidental invasiva a outros povos, da cegueira para com tudo aquilo que apresenta uma alternativa realmente drástica, radical, na maneira como nós experimentamos o mundo.

As possibilidades de banalização da palavra outro são imensas. As possibilidades de mesmificar o outro são infinitas. Do meu ponto de vista, o grande livro que serve de marco para pensar esta questão, menos a palavra outro, que não é uma palavra pela qual eu tenha particular afeição, e também não tenho nenhuma desafeição, mas muito mais a noção de diferença, tal como ela vai ser articulada pelo Deleuze, é o Diferença e repetição, um livro dos mais importantes da filosofia do século XX, e que diz claramente que o que ele está fazendo ali é amarrando uma deriva. Está sintetizando um movimento que já vem se esboçando na filosofia ocidental desde algum tempo e que é uma reavaliação radical do papel, do lugar da diferença na metafísica. E eu acho que a questão da alteridade está ali dentro como o outro, como a diferença humana feita carne.

Aletria - E que produz a linguagem. O mundo sem outrem seria o mundo sem linguagem, como diz lá o Michel Tournier.

Viveiros de Castro - O outro como destino não quer dizer que esteja lá nos esperando. É um destino que você tem que alcançar. Você que vai virar outro. A alteridade não é uma exterioridade, por isso falei, num texto que estou escrevendo, que eu não gosto da palavra alteridade, menos por causa do alter, mais por causa do idade, como se fosse um estado fixo, uma condição existente. Gosto mais da palavra alteração, porque é de fato o que acontece. Palavra boa é alienação, mas foi usada em sentido completamente oposto a tudo que eu gostaria que ela significasse. Tem a ver com o outro qualquer e não o 
outro do eu, enquanto o alter é sempre de dois. Alienação é alheio e é um processo, não uma condição dada, fixa, constituída. Gosto mais da palavra alteração porque ela sugere que o outro não é um espelho, mas é um destino. Quando digo que o outro é um destino, não é que você se identifique com o outro; é porque você se altera. É completamente diferente.

Às vezes, a palavra alteridade vem como naquela língua do Orwel, a novilíngua: você fala alteridade para dizer identidade, fala diferença para dizer mesmidade, fala outro para dizer eu. É preciso evitar esta novilíngua. A frase do Rimbaud é muito interessante: "o eu é um outro" e não o outro, e quando ele escreve o JE, as duas letras são maiúsculas. Então não sou eu que sou o outro, mas enquanto pronome, aquele que diz eu é outro. $\mathrm{O}$ ato de dizer eu designa um outro.

Aletria - Por isso acho que um texto fundamental pra nós é aquele do Lacan, "Lituraterras" (que inspira nosso grupo de pesquisas, o Literaterras). Ele diz que a letra é aquilo que aparece quando se esgarça o sujeito, surge como lixo, marca, e fica entre o saber e o gozo. Esta idéia é muito interessante para trabalhar com os indios nesse processo da escolarização. Entre o saber e o gozo, como se fosse aquilo que bordasse um buraco entre a consciência e o dom poético, algo se escreve.

Viveiros de Castro - Você não sabe o que está acontecendo. Será que eles sabem o que está acontecendo? Certamente eles não sabem, num sentido de saber o que está acontecendo, num suposto saber do que está acontecendo; não é que eles não saibam, mas a gente também não sabe. Tudo pode acontecer, e ao mesmo tempo tudo pode ser um desastre, não dar em nada, tudo pode ser um gigantesco equívoco, um arremedo, uma coisa que não vai dar em nada, que vão ser uns garranchos perdidos sem nenhuma importância. É difícil saber. Às vezes eu fico com a sensação: isso aí que eles estão produzindo é desenho de criança ou pintura abstrata? Não sei.

Aletria - É exatamente esse não saber é que é o mais interessante.

Viveiros de Castro - Quem disse que desenho de criança é ruim? Só que desenho de criança é desenho de criança e pintura abstrata é pintura abstrata, mas tem um lugar em que elas se comunicam, profundamente, evidentemente, um lugar em que a distinção entre desenho de criança e pintura abstrata já não existe mais, porque o pintor abstrato é aquele que pinta como criança, enquanto que o desenho onde a gente vê criança, é uma criança querendo pintar como gente grande, não, o desenho de criança é quando uma criança quer pintar como um adulto e aí a gente chama de desenho de criança, enquanto que você pode imaginar um grande Picasso. Picasso pintava como uma criança, no sentido radical da palavra. Ele teve que desaprender a pintar, como uma criança querendo pintar como um adulto; teve que desaprender a pintar como um adulto para poder pintar como uma criança. Os índios vão ter que fazer a mesma coisa, só que é um índio querendo escrever como um branco, ou é um branco escrevendo como índio? Vai ter uma hora que eles vão ser, sei lá, vai 
ter uma escritura indígena que vai surgir dessa alegre indecisão e não dessa triste contradição, a do ser. O índio, você poderia dizer, vive a triste contradição de ser o branco e não ser nada, mas é interessante que você poderia dizer a mesma coisa, então é como se você pudesse sempre dizer isso de alguém, de ele viver a triste contradição de ser o outro (que no fundo é o eu), porque o outro para o brasileiro é o outro que na verdade é o grande eu, é o eu-europeu, é o modelo do eu que o brasileiro não consegue ser, e dá impressão que não ser nada é ser índio. Para o brasileiro é ser o outro ou ser índio, porque esse outro aí não é o índio, esse outro que ele está falando é o outro europeu.

Aletria - E então ser nada é o índio, esse nada que é a tabula rasa...

Viveiros de Castro - Mas aí é um caso oswaldiano, e que afinal de contas é a solução do "Meu tio o Iauaretê", que o cara vira onça, mas ele não vira onça, essa é uma leitura fenomenológica do conto do Guimarães, que é um onceiro que vira onça, ele é um mestiço que vira índio, porque ele é filho de mãe índia com pai branco. E todo o processo que ele está contando é como é que ele vai virando, é um devir índio de uma onça, tanto quanto o devir onça de um índio, porque no começo ele não é nem uma coisa nem outra, ele é um mestiço caçador de onça, um bugre, um índio de segunda, um índio mestiço, um índio que não é índio, que não tem família, que não tem nada, e que vai...

Aletria - ...e que vai perdendo a língua, vai perdendo a língua portuguesa...

Viveiros de Castro - Pois é, a língua portuguesa vai desaparecendo por subtração, vai subtraindo o português, vai aparecendo a língua geral, o Tupi, e ele vai virando índio, isto é, onça. E naturalmente, e esse me parece que é um conto do Guimarães que não reflete a estrutura dos contos, ele tem que morrer para o conto aparecer; ele precisa ser morto, porque quem conta esse conto é o branco, que foi lá e que não aparece nunca, que nunca está lá. O Guimarães, não sei se ele inventa, mas ele aperfeiçoa, de qualquer maneira, esse estilo, um certo estilo extremamente complexo, que vai aparecer no Grande sertão, em que o narrador aparece nas palavras do narrado e ao mesmo tempo o narrado, que é o que fala, a voz ativa, morre no final.

Aletria - Várias vezes os Maxakali repetiram: "Nós fazemos livros porque nós temos a letra". Ou seja, quando eles fazem livro, a gente é obrigado a fazer em linguagem alfabética, mas o que a gente chama de letra, no sentido lacaniano, eles têm, quer dizer, eles têm uma escrita que talvez seja muito mais poderosa do que a nossa.

Viveiros de Castro - A letra deles é a letra mesmo do Derrida.

Aletria - Exatamente. Aquela que o verdadeiro Maxakali faz. Ser Maxakali, ou ser o xunin (morcego), é um ato de ler.

Viveiros de Castro - O que eles estão fazendo é tentando. Isso é uma coisa fascinante, eles têm a letra, mas eles não têm as letras, não é? E como é que faz uma população que tem a letra, mas não tem as letras? 
Aletria - E como faz com que a letra não se apague? Não tem que ser com letras? Como uma sobreimpressão, como uma refração, conforme a gente estuda em Física: põe a colher dentro da água no copo e ela fica torta. Então, como fazer assim na universidade?

Viveiros de Castro - Quebrar o bastão.

Aletria - A ilusão de ótica. Assim, quer dizer, como não haver uma superposição que...

Viveiros de Castro - ...esconda a diferença.

Aletria - Que esconda a diferença, mas que se dê na multiplicidade. Isto tem a ver com a última pergunta: a multiplicidade é possível no Estado?

Viveiros de Castro - Essas produções indígenas suscitam sempre, num leitor ocidental culto, a idéia de coisas de criança. E tem aquele negócio que o Levi-Strauss fala, tudo aquilo que é estranho, que é radicalmente de outra cultura, inevitavelmente nos faz pensar nas nossas crianças ou nos loucos, porque são justamente seres de nossa cultura que estão em contato com virtualidades que nossa cultura não realizou. Então não é de admirar que uma produção indígena qualquer pareça infantil aos nossos olhos e, aliás, quer dizer, nós pareçamos infantis aos olhos deles, pelas mesmas razões que eles parecem infantis para nós, porque nós exprimimos qualidades que, na cultura deles, não são implementáveis. Então é uma coisa que só criança faz. Os sons, criança pode produzir qualquer som, mas quando aprende a falar, tem uma porção de sons que ela esquece; para ela poder falar uma língua, ela tem que esquecer uma série de sons que ela sabia fazer. Da mesma maneira, eu acho que essas produções indígenas têm um ar pueril por duas razões inteiramente diferentes, e esse me parece que é um ponto a que seria interessante ficar atento. Tem uma razão que é o fato de que se trata de uma pessoa, de um indivíduo de uma comunidade que está aprendendo a domesticar um determinado instrumento, como uma criança que está aprendendo a domesticar um certo instrumento; mas tem um outro lado, que não é nada disso, é que o que ela está fazendo ali não tem coisa alguma a ver com o que nós fazemos, e isso também parece coisa de criança, também parece infantil.

Aletria - Por quê?

Viveiros de Castro - Porque é uma outra coisa muito diferente e que nós não fazemos.

Aletria - Porque é novo.

Viveiros de Castro - Porque é novo, porque é uma coisa que nós mal desconfiamos o que seja. Um dia talvez já tenhamos passado perto daquilo, mas já esquecemos. Não é porque é infantil, é porque é alienígena, radicalmente. Agora eu acho que essas duas coisas são muito difíceis de distinguir num momento histórico em que essas pessoas indígenas estão fazendo as duas coisas ao mesmo tempo. São índias e aprendendo o bê-a-bá, literalmente, desde a caligrafia até o uso 
correto das preposições, a arte das preposições, e usando as duas coisas juntas. Como que eu sei quando é que eles estão usando de um jeito indígena ou de um jeito errado, digamos assim? É possível separar essas duas coisas? Um uso "errado" do português, um uso "indígena” do português? Só vai ser possível separar, se é que é necessário - mas a universidade, até certo ponto, tem essa função de separar essas duas coisas - o uso certo do português para ele poder fazer um uso indígena... Mas nesse processo, ele vai matar alguma coisa, se for "por aî". Enquanto que, deixando a coisa como está, nesse momento de indecisão, de superposição quântica, superimpressão, como você chama, que nem o gato da famosa experiência quântica... tanto pode estar vivo como pode estar morto. Quando abrir a caixa, aquilo pode dar em nada, pode dar em uma expressão artística, estética, filosófica, completamente inaudita. Acho que isso está acontecendo agora: não se sabe o que está acontecendo. Isso aí é um esforço pueril de um índio que mal sabe segurar o lápis ou é a letra Maxakali?

Aletria - Pois é, mas quem que vai decidir isso?

Viveiros de Castro - Acho que nem você, nem eles, nem nós. Acho que é uma coisa que vai... acho que não está decidido, portanto, não sei quem vai decidir. Certamente, se, por exemplo, o Estado permitir que isso aconteça, já está decido. Decidir está fácil, é só suspender um tipo de auxílio, apoio e suporte, daí, já se decidiu. Qual é a decisão? Não vamos poder saber. Isso é coisa de criança. Ou temos que botar esses índios para virar branco e parar com essa bobagem. Depois, se eles quiserem, eles que recuperem a cultura deles, como os italianos recuperaram a literatura grega no Renascimento. Vão voltar para buscar uma coisa quinhentos anos depois? Eu realmente não sei. Agora eu vejo como uma sensação de que, quando você ouve, é como um mito indígena. Você pode ler como tal, por isso é tão fácil adaptar os indígenas para historinhas de criança. Por quê? Porque ele é muito estranho, não é que ele seja muito simples, ele é muito estranho e, portanto, acessível às crianças.

Aletria - Porque não tem lógica, a mesma lógica; é o non sense que comanda. E o Guimarães Rosa, aliás, os poetas, os criadores da língua, os verdadeiros escritores, se é que se pode dizer assim, são justamente aqueles que dão suporte, dão algum aval nessa experiência nossa com os indios, sabia?

Viveiros de Castro - Uma coisa que a gente tem e que eles não têm diante deles.

Aletria - Porque eles querem isso.

Viveiros de Castro - Talvez um antropólogo muito experiente até possa ter, mas que a gente a princípio não tem, enquanto não antropólogo, não especialista, não familiarizado com aquele ou este grupo: é aquela discriminação meio intraduzível em regra, mas que a gente tem na cabeça, que é quando a gente é capaz de olhar, ouvir, ler uma poesia que, à primeira vista, uma pessoa não treinada pode confundir com um monte de palavras sem sentido juntadas e 
você é capaz de dizer: "Não, isso aí é genial". E é uma coisa que para uma pessoa não treinada é: "Não, isso não vale nada, isso aí é só um monte de palavras sem sentido". Essa capacidade de avaliar isso, que é a mesma que tem o cara que entende de música ouvindo um improviso de jazz, e dizer: "Isso aqui é maravilhoso". E outro que não ouve: "Isso aqui para mim é um monte de sons". Isso aí a gente não tem em relação aos índios? Justamente esse faro para distinguir o que é completamente inaudito e aquilo que é apenas uma coisa rudimentar, de alguém que está aprendendo a dominar uma linguagem? A gente não sabe qual é a deles, a gente não conhece a cultura deles o suficiente para saber distinguir isso.

A gente não sabe como pensa o Maxakali, ninguém sabe a língua Maxakali, ninguém viveu com Maxakali tempo suficiente para saber como é ser um Maxakali. Tem um célebre artigo de um filósofo, Thomas Nagel, o nome do artigo é "Como é ser um morcego" ("How would you like to be a bat?") e a conclusão dele é a de que é preciso ser um morcego para saber o que é ser um morcego; e o engraçado é que sendo o morcego para os Maxakali, talvez os Maxakali saibam como é ser um morcego e, portanto, eles responderam a essa questão do famoso artigo do Nagel de um jeito que a gente não esperava. Nós não temos a cultura suficiente para distinguir, nas produções, nessas novas formas indígenas de expressão, que envolvem o uso de instrumentos simbólicos brancos; instrumentos para distinguir-lhes o valor. A minha impressão é essa, nós não temos ainda!

Aletria - Eu diria que não temos do ponto de vista deles, mas a gente tem do ponto de vista nosso. Trabalho com literatura indígena cativada por um poema, "Eu pensava que a Terra remendava com o Céu". Li esse poema, de um professor lá do Acre, Norberto Tene Kaxinawá, e achei de uma, como diria o Haroldo de Campos, alta voltagem poética, e depois li "Antes o mundo não existia", aquele livro que Berta Ribeiro organizou com os Desana e fiquei impressionada, há muitos anos eu não lia nada tão, tão interessante. Estou cansada de ir a congressos e as pessoas questionarem: com que critério considero isso literatura? Esses textos são pueris, como compará-los com os de um escritor qualquer? Mas eu não comparo. Estou na perspectiva da Llansol: "Não há literatura. Importa saber em que real se entra e se há técnica adequada para abrir caminhos a outros."

Viveiros de Castro - Se o que importa é saber em que real se entra, e para eles? Em que real eles estão entrando? Então vamos dizer que não cabe a nós quantificar a respeito, só a eles. E se eles tiverem instrumentos, eles vão quantificar para nós, se não, eles vão continuar no silêncio eterno deles, lá. 